\title{
The Eternal Question: Biological variations on a Platonic dialogue ${ }^{1}$
}

\author{
Jakob von Uexküll, Thure von Uexküll ${ }^{2}$
}

\begin{abstract}
The reinterpretation of Nature by biology, which will prevail in spite of all obstacles, has brought our thinking closer to antiquity, giving us the chance to reinvigorate our perused terminology with the help of the resources to be found in the thoughts of the greatest minds of mankind. The way to Plato thus being cleared, I perceived the idea to seek enlightenment on pressing biological questions from the great Sage. As means to this end, I chose to make Socrates continue one of his dialogues, with the adjustment of giving him the knowledge of our contemporary biological problems. Thus some kind of interaction between the Ancients and ourselves is created, to our considerable benefit. $^{3}$
\end{abstract}

If death were a release from everything, it would be a boon for the wicked, because by dying they would be released not only from the body but also from their own wickedness together with the soul.

Plato, Phaedo (107c)

1 The original: Uexküll, Jakob von; Uexküll, Thure von 1943. Die ewige Frage: Biologische Variationen über einen platonischen Dialog. Europäische Revue 19(März): 126-147. It was also published as a booklet: Uexküll, Jakob von; Uexküll, Thure von 1944. Die ewige Frage: Biologische Variationen über einen platonischen Dialog. Hamburg: Marion von Schröder Verlag. Translated by Edgar Vögel.

2 Part One of this text is the work of J. von Uexküll. It is followed by a continuation (Part Two) authored by his son, Thure von Uexküll, based on a letter responding to the father. Insofar, the whole piece represents a dialogue between father and son on Plato's Meno dialogue.

3 This abstract (in German) has appeared as a footnote on the p. 126 of the original. 


\section{First Part}

On the front of an imposing blue painted half-timbered farmhouse in Upper Hesse one finds an inscription, intended as a serious admonition to passersby. The inscription reads: Where do you want to spend eternity?

This motto could as well have been inscribed on a farmhouse in ancient Athens. For people of all centuries were aroused by the question of man's personal immortality, giving now a positive now a negative answer.

Thus it may not be without interest to take up the evidence, as far as it is of biological interest, that has been brought up for the existence of personal immortality, and to link the different pieces of evidence; this is best done by taking up the one of Plato's dialogues that has until now given the most convincing argument, and by linking it with our biological discoveries, thus reexamining its reliability.

In order to create a vivid picture of the Platonic dialogue, we take ourselves on an imaginary journey back to ancient Athens, the scene of our drama.

The columned court of a large villa opens towards a garden surrounded by a marble balustrade. In the garden grows an abundance of laurel bushes offering shadow, with cypresses standing out here and there. Above the green of the garden shine the distant yellow columns of the Parthenon and above them in steel-like blue the blinding rays of the Greek sky.

In the shadow of the columns, comfortably seated on a chair, sits the Master, who is enthusiastically admired by the Athenian youth. His sophisticated complexion, with its friendly bright eyes, leaves no one unimpressed. His small hands with their agile fingers readily accompany his words.

Next to him, leaning against a column, stands the noble stature of his host, easily recognizable as someone refined in the art of living. His delicately shaped lips seem to be up to some witty remark. Not far from them, on the balustrade, sits a young man with beautiful noble features. In his hand he holds a wax tablet on which he occasionally carves his notes, each time the course of the conversation reaches a climax. Through him it is that posterity received the tidings of this conversation. 
Being called by his master, a servant of the household, almost still a boy, with frank and intelligent features, joins these men. Whereas the three free citizens are dressed in long white robes covering the whole body, the slave's bare chest shines in a luxuriant reddishbrown. -

This roughly is what we shall imagine the stage set to be like, which is about to gain brilliance and meaning through the dialogue recorded by Plato.

It is easy to describe the background of this scene for one's body's eye. A wholly different task arises for us in painting the background to be presented to one's mind's eye. But it is absolutely necessary to give account for the intellectual background. We have to know these preconditions which are taken as granted by the characters of the dialogue in such a manner that they will not make mention of them; otherwise we will not be able to fully comprehend their words.

Recently Otto's great works have introduced us to the Greeks' concept of their gods and of Nature. But this concept is miles apart from our contemporary concept of Nature, so that we have to feel our way back to the Greeks' world view step by step. -

As starting point I take a conversation which, although it has come down to us only in way of an anecdote, is full of insight. During the first years of the last century, shortly after ascending the imperial throne, Napoleon paid a visit to the famous astronomer Laplace and his newly erected observatory. The first useful telescopes made it possible to gain a clear image even of distant stars.

Napoleon had himself introduced by Laplace to the wonders of the cosmos. He felt like he was entering an enormous dome, the dimensions of which his searching eyes could not measure. The cosmic dome rose higher and higher. This dome, created from many lights, did not rest, but everything in it was majestically moving. It seemed to the emperor as if he could hear the music of the spheres.

Laplace kept talking on and on, about rotating motions and about numbers, numbers and again numbers. After he had finished the emperor leaned back where he sat, looked at him with his piercing eyes and asked: "And you don't say anything about the Spirit who created this wonderful world?"

"Sire, nous n'avons pas besoin de cette Hypothèse" (Sire, we don't have any need for this hypothesis.") was Laplace's answer. The emperor looked at him for a long time and finally said mockingly: 
"Vous finirez par corriger la Nature." ("You will end up improving Nature.)

This conversation presents to us an instance of two fundamentally different ways of viewing Nature. Laplace took the position of an uninvolved observer, standing on the outside of the starry vault whereas Napoleon took his position right in the middle of Nature, standing on this Earth, taking part in the dancing of the constellations.

The emperor's prophetic words should come true soon. Without God's hands holding it together, the universe turned into a mere astronomical machinery. Instead of illuminating the dome of endless space erected to glorify God, the stars were assigned the new role of senselessly rotating around each other as part of a giant cosmic machine.

The cosmic machine, having come into being by accident, indeed turned out to be defective. There literally was a shower of cosmic rubble in space.

After it came to light that the existence of living organisms was at best possible only on a few lonely planets in an endless space, Nature began to lose more and more respect with the general public. As far as the physicists were concerned, the living things were also integrated into the great cosmic machine as tiny mechanisms. Their expressions of life, as thoughts and emotions, were reduced to chemical processes in the brain.

It was Loeb who went the furthest in mechanizing the cosmos by reducing the whole life of animals to a mere reactive turning of the animal bodies away from or towards all external stimuli.

But the decisive attack on Nature was led by Darwin. He declared her to be a blind idiotic being. Having come into existence by chance she could as good perish by chance; because all living creatures are permanently caught up in their mutual annihilation, what Darwin called the struggle for existence, which supposedly gives rise to evolution by survival of the fittest. The world was like a battlefield of automatic tanks, and Nature only a scene of devastation inhabited by soulless freaks. -

In comparison to this, Jennings' doctrine looks more moderate. After observing the behavior of individual animals, which reached a goal through many attempts, he traced the evolution of species back to trial and error. He overlooked that he was putting Nature in the role of a petty-minded small shopkeeper, who after many setbacks in 
conducting his business learns to be clever through experience. But whereas learning by experience seems to be appropriate for individual creatures, it would be unworthy behavior for Nature as Creator.

Being thus, it takes no wonder why the general public was filled with an ever-more deepening contempt for Nature.

The campaign against the religious view of Nature celebrated one triumph after another. In the lower house of the French parliament, the Deputy Viviani proclaimed under the frenetic applause of the chamber: "Avec un geste magnifique, nous avons éteint tous les astres du ciel!" ("By a magnificent gesture we have extinguished all the stars in the sky.") Thus the cosmic dome, which Napoleon not long before had entered reverently, finally collapsed. -

But science itself is the place where the tide turns. The physical scientists are turning away from observing space and time from the outside and are entering space itself. The concept of time as flowing through the universe, passing at the same speed everywhere, has been left behind. The physicist judges the events in time from a point in space, and if the point in space changes, so do the relations in time. From a point of view $A$, two events, let's say two gunshots, may occur simultaneously, given the observer stands halfway between the two gunmen. From a point of view $B$, closer to one of the gunmen, that gunman's shot will move faster in time. This kind of consideration led to the introduction of time ordinates for every system of spatial coordinates and finally to the concept of a four-dimensional spacetime continuum.

The cosmic machine was replaced by the world formula, i.e. matter was replaced by an idea. The idea of Nature was lost in the process. From here the way back to Greece cannot be found. -

But now the understanding that we have to observe not from the outside, but from the inside, dawns even on biologists.

I take the example of a fly having a walk on a desk. Nowadays we know that the feet of flies are equipped with organs for tasting, so if the fly steps on some kind of food suitable for flies it immediately sticks it proboscis out for it. Everything that is found on the desk, whatever variety of things it may be, like matches, postage stamps, pencils or sealing wax - to the fly all these things have the same meaning as to us the floor we walk on. The fly is simply surrounded by fly things and does not know human things. The owner of the desk 
does not exist within the fly's environment, he exists outside the range of its comprehension.

It is impossible for us to enter a fly's soul in order to find out what it feels, but we are able to establish those things or matters that are important to flies, that are appropriate to them. Instead of trying to feel ourselves into the fly's soul we are able to follow the fly's life as observers. Thus we are able to establish those things that are regarded by the fly as appropriate to itself, may it be as its food, or as its enemy, or as an obstacle, or as a mating partner.

The biological study of insect colonies brought forth an abundance of discoveries. Entering an imaginary beehive, anthill or termites' nest, we are not to look for human things, but for bee, ant or termite things, by this means opening to ourselves new wondrous worlds. Laying before our eyes we find great empires, the peoples of which are connected with each other by industrious intercourse; we are enabled to study their work, their building, their care for their brood and the laws of their government.

This actually means to view Nature from inside. Only then Nature reveals her true greatness. Only then we understand Nature's confidence in distributing her gifts to every of her creatures, both physical and spiritual gifts. It assigns, so to speak, to every living subject, be it an animal or a human being, its faculty of sensing (Merkfähigkeit) and its faculty of action (Wirkfähigkeit). And if anyone feels compelled to complain because he regards the dose of intellect and reason assigned to him as too modest, he is free to do so; but he shall not maintain that Nature, who bestows all those gifts, lacks them herself. The habit of uselessly criticizing Nature must come to an end, it will only make contemporary science look stupid for all time.

Considering the above, we are getting a good step closer to the Greeks. Even in his wildest dreams a Greek would never have ventured to criticize Nature.

Nature is like a solemn symphony, all of the thousands of different voices interwoven into one score of music. Speaking with Bilz, ${ }^{4}$ Nature performs for us a cosmic drama consisting of thousands of interwoven dramas. The dramas present a sequence of "living scenes", the scripts of which are predetermined. The actors change, but the play is repeated again and again, generation after generation.

4 Bilz, Rudolf 1940. Pars pro toto. Leipzig: Georg Thieme. 
Later on we are going to see in what way this concept of Nature approaches the Greek one. First we have to state more precisely what separates Greek religion from the Christian church.

"I believe in one God, the Father, the Almighty, Creator of heaven and earth" - this is the beginning of the Christian creed. Without doubt, God is seen here as standing outside of Nature. Our senses are able to comprehend Nature, but not God. But he is not only the Creator and ruler of Nature, but also of man's destiny. Often Nature is nothing more to him than a means to influence man's destiny. But often it is Nature herself who leads man astray from the path of God. Thus arises a permanent antagony between God and Nature.

This kind of thoughts was far from the Greeks' minds. To them, visible Nature was the divine, without any connection to man's destiny. The visible gods, as heaven, sea and earth, only provided the scenario on which the human dramas took place, written by destiny.

The gods are without destiny, they live in an eternal present, youthful and happy. But man, bound by destiny, leaves the past, passes through the present and enters an uncertain future. The gods, to whom were attributed human souls, would from time to time, assuming human figure, descend on earth to stand by their favorites. But they were always close to man. He just had to open his eyes to see heaven, earth, see, sun and moon, the immutable witnesses of all human events. - Only one god is different from the other immortals; it is Dionysus, the god of human destiny, the ups and downs of which found their shocking expression in the mysteries of Eleusis.

The Greeks knew all that is human. The small group around Socrates in Meno's columned court was in the first place, besides other things, concerned with the question of the past, including the question of death.

The conversation had started with Meno's question: if virtue could be taught or not. Socrates' questions led the conversation to take a surprising turn. Meno himself was not sure anymore what was meant by virtue. He was, in his own words, confused like he had been hit by a stingray. On Socrates' request to ascertain the unknown nature of virtue together with him, he replied: But how will you look for something when you don't in the least know what it is? How on earth are you going to set up something you don't know as the object of your search? To put it another way, even if you come right up against 
it, how will you know that what you have found is the thing you didn't know $?^{5}$

Meno's attack is not just aimed at Socrates, but inasmuch against all scientific study. To Meno, study is the same as a mere searching. But one always searches only for an already known object. Unsystematic searching and well-trained research, indissolubly linked to all scientific discovery and insight, get indeed mixed up quite often. Serious research can of course be aimed at an unknown goal, as long as it does not disregard the fundamental context.

Socrates regards Meno's words as a sophistic trap which he uncovers at once.

$\mathrm{S}$ o c r a t e s: I know what you mean. Do you realize that what you are bringing up is the trick argument that a man cannot try to discover either what he knows or what he does not know? He would not seek what he knows, for since he knows it there is no need of the inquiry, nor what he does not know, for in that case he does not even know what he is to look for.

Meno, regarding Socrates' studies as unsystematic experimenting, thinks the sophistic argument to be appropriate and asks: Well, do you think it a good argument?

No, replies Socrates, and now he develops his doctrine, which he adopted from those regarded as having inspiration, i.e. the human soul being immortal and having acquired during numerous subsequent forms of existence some amount of knowledge which just rests forgotten inside man. The purpose of all learning is to resurrect this knowledge, learning being nothing else than remembering knowledge from a former existence.

$\mathrm{M}$ e n o : Can you explain how it fails?

$\mathrm{S}$ o $\mathrm{c} \mathrm{r}$ a $\mathrm{t} \mathrm{e} \mathrm{s}$ : I can. I have heard from men and women who understand the truths of religion ...

M e n o: What did they say?

$\mathrm{S}$ o c r a t e s: Something true, I thought, and fine.

$\mathrm{M}$ e n o: What was it, and who were they?

$\mathrm{S}$ o $\mathrm{c} \mathrm{r}$ a t e s: Those who tell it are priests and priestesses of the sort who make it their business to account for the functions which they perform. Pindar speaks of it too, and many another of the poets who are divinely inspired. What they say is this - see whether you think they are speaking the truth. They say that the soul of man is immortal.

5 Plato, Meno (80d). 
At one time it comes to an end - that which is called death - and at another is born again, but is never finally exterminated. On these grounds a man must live his days as righteously as possible. As a poet has said: For those from whom Persephone receives requital for ancient doom, in the ninth year she restores again their souls to the sun above. From whom rise noble kings and the swift in strength and greatest in wisdom, and for the rest of time they are called heroes and sanctified by men.

Sokrates continues: Thus the soul, since it is immortal and has been born many times, and has seen all things both here and in the other world, has learned everything that is. So we need not be surprised if it can recall the knowledge of virtue or anything else which, as we see, it once possessed. All Nature is akin, and the soul has learned everything, so that when a man has recalled a single piece of knowledge - learned it, in ordinary language - there is no reason why he should not find out all the rest, if he keeps a stout heart and does not grow weary of the search, for seeking and learning are in fact nothing but recollection. We ought not then to be lead astray by the contentious argument you quoted. It would make us lazy, and is music in the ears of weaklings. The other doctrine produces energetic seekers after knowledge, and being convinced if its truth, I am ready, with your help, to inquire into the nature of virtue.

Meno has been closely following Socrates' explanations. At once he grasped the essence. If it can be shown that our knowledge is a memory from a former existence, the existence of personal immortality is proven with it. That is why he replies to Socrates: I see, Socrates. Can you teach me that it is so?

$\mathrm{S}$ o c r a t e s: I just said that you're a rascal, and now you ask me if I can teach you, when I say there is no such thing as teaching, only recollection. Evidently you want to catch me contradicting myself straightaway.

M e n o : No, honestly, Socrates, I wasn't thinking of that. It was just habit. If you can in any way make clear to me that what you say is true, please do.

$\mathrm{S}$ o c r a t e s : It isn't an easy thing, but I still should like to do what I can since you ask me. I see you have a large number of retainers here. Call one of them, anyone you like, and I will use him to demonstrate it to you.

M e n o: Certainly. [To a slave boy.] Come here. 
$\mathrm{S}$ o c r a t e s: He is a Greek and speaks our language?

$\mathrm{M}$ e n o: Indeed yes - born and bred in the house.

$\mathrm{S}$ o c r a t e s: Listen carefully then, and see whether it seems to you that he is learning from me or simply being reminded.

M e no: I will.

$\mathrm{S}$ o c r a t e s: (Socrates begins to draw figures in the sand at his feet. He points to the square.) Now boy, you know that a square is a figure like this?

B o y: Yes.

$\mathrm{S}$ o $\mathrm{c}$ a t e s: It has all these four sides equal?

B o y: Yes.

$\mathrm{S}$ o $\mathrm{c} \mathrm{r}$ a $\mathrm{te} \mathrm{s}$ : And these lines which go through the middle of it (Fig. 1, AD-BC) are also equal?

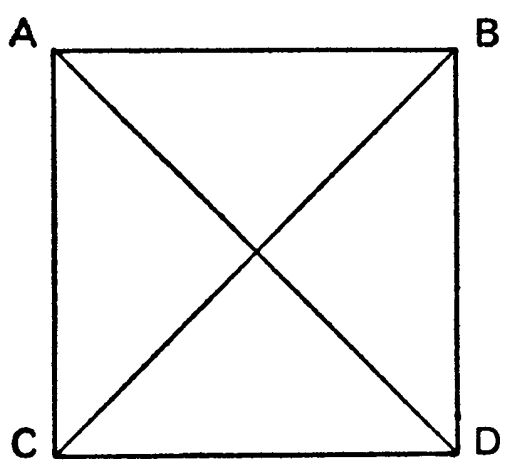

Figure 1.

B o y: Yes.

$\mathrm{S}$ o c r a t e s : Such a figure could be either larger or smaller, could it not?

B o y: Yes.

$\mathrm{S}$ o $\mathrm{c}$ a t e s : Now if this side (AB) is two feet long, and this side (BD) the same, how many feet will the whole be? Put it this way. If it were two feet in this direction and only one on that, must not the area be two feet taken once?

B o y: Yes. 
$\mathrm{S}$ o c r a t e s: But since it is two feet this way also, does it not become twice two feet?

B o y: Yes.

$\mathrm{S}$ o c r a t e s: And how many feet is twice two? Work it out and tell me.

B o y: Four.

$\mathrm{S}$ o $\mathrm{c} \mathrm{r}$ a $\mathrm{t}$ e s: Now could one draw another figure double the size of this, but similar, that is, with all sides equal like this one?

B o y: Yes.

$\mathrm{S}$ o c r a t e s: How many feet will its area be?

B o y: Eight.

$\mathrm{S}$ o $\mathrm{c} \mathrm{r}$ a $\mathrm{t}$ e s : Now then, try to tell how long each of its sides will be. The present figure has a side of two feet. What will be the side of the double-sized one?

B o y : It will be double, Socrates, obviously.

$\mathrm{S}$ o c r a t e s : You see, Meno, that I am not teaching him anything, only asking. Now he thinks he knows the length of the side of the eight-foot square.

M e no: Yes.

S o c r a t e s: But does he?

M e n o: Certainly not.

$\mathrm{S}$ o $\mathrm{c}$ a $\mathrm{te} \mathrm{s}$ : He thinks it is twice the length of the other.

Me no: Yes.

$\mathrm{S}$ o $\mathrm{c} \mathrm{r}$ a t e s: Now watch how he recollects things in order - the proper way to recollect. [To the boy.] You say that the side of double length produces the double-sized figure? Like this I mean, not long this way and short that. It must be equal on all sides like the first figure, only twice its size, that is, eight feet. Think a moment whether you still expect to get it from doubling the side.

B o y: Yes, I do.

$\mathrm{S}$ o $\mathrm{c} \mathrm{r}$ a $\mathrm{t}$ e s: Well now, shall we have a line double the length of this (CD) if we add another the same length at this end (DE)?

B o y: Yes.

$\mathrm{S}$ o $\mathrm{c}$ a $\mathrm{te} \mathrm{s}$ : It is on this line then, according to you, that we shall make the eight-foot square, by taking four of the same length?

B o y: Yes.

$\mathrm{S}$ o $\mathrm{c} \mathrm{r}$ a $\mathrm{te} \mathrm{s}$ : Let us draw in four equal lines, using the first as a base. Does this not give us what you call the eight-foot figure (Fig. 2, GFEC)? 


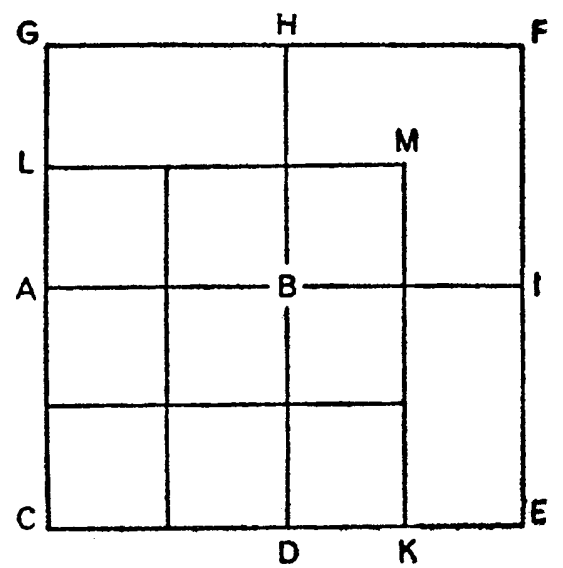

Figure 2.

B o y: Certainly.

$\mathrm{S}$ o $\mathrm{c} \mathrm{r}$ a $\mathrm{t}$ e $\mathrm{s}$ : But does it contain these four squares, each equal to the original four-foot one?

B o y: Yes.

$\mathrm{S}$ o c r a t e s: How big is it then? Won't it be four times as big?

B o y: Of course.

$\mathrm{S}$ o $\mathrm{c} \mathrm{r}$ a $\mathrm{t} \mathrm{e} \mathrm{s}$ : And is four times the same as twice?

B o y: Of course not.

$\mathrm{S}$ o $\mathrm{c}$ r a $\mathrm{t}$ e s : So doubling the side has given us not a double but a fourfold figure?

B o y: True.

$\mathrm{S}$ o $\mathrm{c} \mathrm{r}$ a $\mathrm{te} \mathrm{s}$ : And four times four are sixteen, are they not?

B o y: Yes.

$\mathrm{S}$ o c r a t e s: Then how big is the side of the eight-foot figure? This one has given us four times the original area, hasn't it?

B o y: Yes.

$\mathrm{S}$ o $\mathrm{c}$ a t e s: And a side (fig. 2, CD) half the length (as CE) gave us a square of four feet?

B o y: Yes.

$\mathrm{S}$ o c r a t e s : Good. And isn't a square of eight feet double this one (ABDC) and half that (GFEC)?

$\mathrm{B}$ o y : Yes. 
$\mathrm{S}$ o c r a t e s: Will it not have a side greater than this one (CD) but less than that $(\mathrm{CE})$ ?

$\mathrm{B}$ o y : I think it will.

$\mathrm{S}$ o c r a t e s: Right. Always answer what you think. Now tell me. Was not this side two feet long, and this one four?

B o y: It must.

$\mathrm{S}$ o c r a t e s: Try to say how long you think it is.

B o y: Three feet.

$\mathrm{S}$ o $\mathrm{c} \mathrm{r}$ a t e $\mathrm{s}$ : If so, shall we add half of this bit (DK to $\mathrm{CD})$ and make it three feet $(\mathrm{CK})$ ? Here are two $(\mathrm{CD})$, and this is one (DK), and on this side similarly we have two (CA) plus one (AL), and here is the figure you want.

B o y: Yes.

$\mathrm{S}$ o c r a t e s: If it is three feet this way (CK) and three that (CL), will the whole area (LMKC) be three times three feet?

$\mathrm{B}$ o y: It looks like it.

$\mathrm{S}$ o c r a t e s: And that is how many?

B o y: Nine.

$\mathrm{S}$ o $\mathrm{c} \mathrm{r}$ a $\mathrm{t} \mathrm{e} \mathrm{s}$ : Whereas the square double our first square had to be how many?

B o y : Eight.

$\mathrm{S}$ o $\mathrm{c} \mathrm{r}$ a t e s: But we haven't yet got the square of eight feet even from a three-foot side?

B o y: No.

$\mathrm{S}$ o c r a t e s: Then what length will give it? Try to tell us exactly. If you don't want to count it up, just show us on the diagram.

B o y: It's no use, Socrates, I just don't know.

$\mathrm{S}$ o $\mathrm{c} \mathrm{r}$ a $\mathrm{t}$ e $\mathrm{s}$ : Observe, Meno, the stage he has reached on the path of recollection. At the beginning he did not know the side of the square of eight feet. Nor indeed does he know it now, but then he thought he knew it and answered boldly, as was appropriate - he felt no perplexity. Now however he does feel perplexed. Not only does he not know the answer; he doesn't even think he knows.

M e n o: Quite true.

$\mathrm{S}$ o $\mathrm{c} \mathrm{r}$ a t e s: Isn't he in a better position now in relation to what he didn't know?

$\mathrm{M}$ e n o: I admit that too.

$\mathrm{S}$ o $\mathrm{c}$ a $\mathrm{t} \mathrm{e} \mathrm{s}$ : So in perplexing him and numbing him like the stingray, have we done him any harm? 
M e n o: I think not.

$\mathrm{S}$ o c $\mathrm{r}$ a t e s: In fact we have helped him to some extent toward finding out the right answer, for now not only is he ignorant of it but he will be quite glad to look for it. Up to now, he thought he could speak well and fluently, on many occasions and before large audiences, on the subject of a square double the size of a given square, maintaining that it must have a side of double the length.

M e n o: No doubt.

$\mathrm{S}$ o $\mathrm{c} \mathrm{r}$ a $\mathrm{t}$ e s : Do you suppose then that he would have attempted to look for, or learn, what he thought he knew, though he did not, before he was thrown into perplexity, became aware of his ignorance, and felt a desire to know?

M e no: No.

$\mathrm{S}$ o c r a t e s: Then the numbing process was good for him?

$\mathrm{M}$ e n o: I agree.

$\mathrm{S}$ o $\mathrm{c} \mathrm{r}$ a $\mathrm{t}$ e $\mathrm{s}$ : Now notice what, starting from this state of perplexity, he will discover by seeking the truth in company with me, though I simply ask him questions without teaching him. Be ready to catch me if I give him any instruction or explanation instead of simply interrogating him on his own opinions. [To the boy:] Tell me, boy, is not this our square of four feet (fig. 3, ABDC)? You understand?

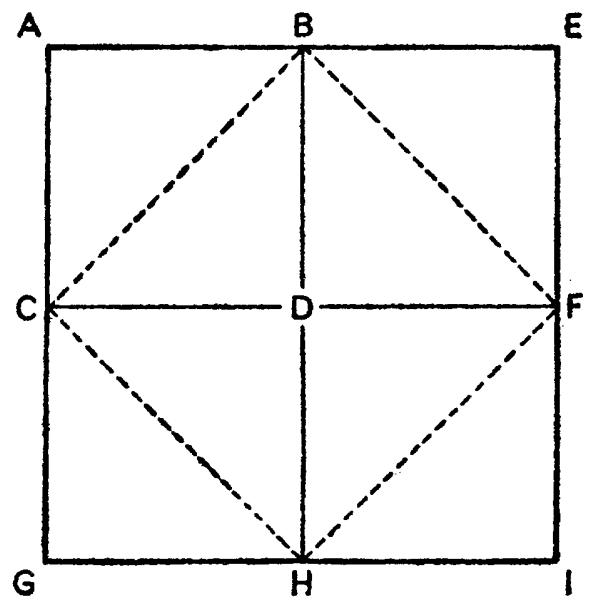

Figure 3. 
B o y: Yes.

$\mathrm{S}$ o c r a t e s: Now we can add another equal to it like this (BEFD)?

B o y: Yes.

$\mathrm{S}$ o $\mathrm{c}$ a t e s : And a third here (DCGH), equal to each of the others?

B o y: Yes.

$\mathrm{S}$ o c r a t e s : And then we can fill in this one (DFIH) in the corner?

B o y: Yes.

$\mathrm{S}$ o $\mathrm{c}$ r a t e s: Then here we have four equal squares?

B o y: Yes.

$\mathrm{S}$ o $\mathrm{c} \mathrm{r}$ a $\mathrm{t} \mathrm{e} \mathrm{s}$ : And how many times the size of the first square is the whole?

B o y: Four times.

$\mathrm{S}$ o c $\mathrm{r}$ a t e s: And we want one double the size. You remember?

B o y: Yes.

$\mathrm{S}$ o $\mathrm{c} r$ a t e s: Now do these lines going from corner to corner (CB, BF etc.) cut each of these squares in half?

B o y: Yes.

$\mathrm{S}$ o $\mathrm{c} r$ a t e s: And these are four equal lines enclosing this area $(\mathrm{BCHF})$ ?

$\mathrm{B}$ o y: They are.

$\mathrm{S}$ o c r a t e s: Now think. How big is this area?

B o y: I don't understand.

$\mathrm{S}$ o $\mathrm{c} \mathrm{r}$ a $\mathrm{t} \mathrm{e} \mathrm{s}$ : Here are four squares. Has not each line cut off the inner half of each of them?

Boy: Yes.

Socrates: And how many such halves are there in this figure?

B o y: Four.

$\mathrm{S}$ o c r a t e s: And how many in this one (ABDC)?

B o y: Two.

$\mathrm{S}$ o $\mathrm{cr}$ a t e s: And what is the relation of four to two?

B o y: Double.

$\mathrm{S}$ o $\mathrm{c}$ a t e s: And how big is this figure then?

B o y: Eight feet.

$\mathrm{S}$ o c r a t e s: On what base.

$\mathrm{B}$ o y: This one $(\mathrm{CB})$. 
$\mathrm{S}$ o c $\mathrm{r}$ a $\mathrm{t} \mathrm{e} \mathrm{s}$ : The line which goes from corner to corner of the square of four feet?

B o y: Yes.

$\mathrm{S}$ o c r a t e s: The technical name for it is 'diagonal'; so if we use that name, it is your personal opinion that the square on the diagonal of the original square is double its area.

B o y: That is so, Socrates.

$\mathrm{S}$ o c r a t e s: What do you think, Meno? Has he answered with any opinions that were not his own?

$\mathrm{M}$ e n o: No, they were all his.

$\mathrm{S}$ o c r a t e s: Yet he did not know, as we agreed a few minutes ago.

M e no: True.

$\mathrm{S}$ o c $\mathrm{r}$ a $\mathrm{t}$ e $\mathrm{s}:$ But these opinions were somewhere in him, were they not?

M e no: Yes.

$\mathrm{S}$ o c r a t e s: So a man who does not know has in himself true opinions on a subject without having knowledge.

$\mathrm{M}$ e $\mathrm{n}$ o: It would appear so.

$\mathrm{S}$ o c r a t e s : At present these opinions, being newly aroused, have a dreamlike quality. But if the same questions are put to him on many occasions and in different ways, you can see that in the end he will have a knowledge on the subject as accurate as anybody's.

M e no: Probably.

$\mathrm{S}$ o $\mathrm{c} \mathrm{r}$ a $\mathrm{t}$ e $\mathrm{s}$ : This knowledge will not come from teaching but from questioning. He will recover it for himself.

M e n o: Yes.

$\mathrm{S}$ o $\mathrm{c}$ a t e s: And the spontaneous recovery of knowledge that is in him is recollection, isn't it?

M e no: Yes.

$\mathrm{S}$ o $\mathrm{c} \mathrm{r}$ a $\mathrm{t}$ e $\mathrm{s}$ : Either then he has at some time acquired the knowledge which he now has, or he has always possessed it. If he always possessed it, he must always have known; if on the other hand he acquired it at some previous time, it cannot have been in this life, unless somebody has taught him geometry. He will behave in the same way with all geometric knowledge, and every other subject. Has anyone taught him all these? You ought to know, especially as he has been brought up in your household.

M e n o: Yes, I know that no one ever taught him. 
S o c r a t e s: And has he these opinions, or hasn't he?

$\mathrm{M}$ e $\mathrm{n}$ o: It seems we can't deny it.

$\mathrm{S}$ o $\mathrm{c} \mathrm{r}$ a $\mathrm{t} \mathrm{e} \mathrm{s}$ : Then if he did not acquire them in this life, isn't it immediately clear that he possessed and had learned them during some other period?

M e n o : It seems so.

$\mathrm{S}$ o $\mathrm{c}$ a $\mathrm{t}$ e $\mathrm{s}$ : When he was not in human shape?

M e no: Yes.

$\mathrm{S}$ o $\mathrm{c} \mathrm{r}$ a t e s: If then there are going to exist in him, both while he is and while he is not a man, true opinions which can be aroused by questioning and turned into knowledge, may we say that his soul has been forever in a state of knowledge? Clearly he always either is or is not a man.

M e n o: Clearly.

$\mathrm{S}$ o c r a t e s: And if the truth about reality is always in our soul, the soul must be immortal, and one must take courage and try to discover - that is, to recollect - what one doesn't happen to know, or, more correctly, remember, at the moment. ${ }^{6}$

At this point we interrupt the scene, and we are going to continue after making no more changes to it than to give Socrates the possession of our contemporary biological knowledge.

$\mathrm{M}$ e $\mathrm{n}$ o : In considering such a serious and important question, as the existence or non-existence of personal immortality is one, I would be grateful to you, Socrates, if you could offer me one more proof for the existence of knowledge from a former life.

$\mathrm{S}$ o c r a t e s : My dear Meno, does it not seem to you that our existence is similar to the tragedies of Sophocles and Euripides, insofar as it consists of nothing but a sequence of individual scenes?

M e n o : Certainly, Socrates, the great poets attempted to make us aware of life itself, and therefore rendered for the stage the scenic sequence of life's events.

$\mathrm{S}$ o c r a t e s: And did not the poets attempt to clarify through the sequence of scenes destiny's influence on man's soul?

M e n o : Certainly. They assign to every actor his detailed part consisting of words and gestures.

6 Plato, Meno (86b). 
$\mathrm{S}$ o c r a $\mathrm{t}$ e $\mathrm{s}$ : Now, are the assigned words and gestures announced directly to the actors by the poet or one of his representatives during the performance?

$\mathrm{M}$ e $\mathrm{n}$ o : Not at all, Socrates. The actors already have to know their parts by heart when they enter the stage.

$\mathrm{S}$ o c r a t e s : Did they not, before finally performing, rehearse the whole play, in order to recite it without mistake to the people of Athens?

M e n o : Certainly. Otherwise they would create an awful chaos on stage instead of depicting life.

$\mathrm{S}$ o c r a t e s : Therefore we can say, that the drama simply consists of the actors' memories of the rehearsal they lived through earlier.

M e n o : We can say so.

$\mathrm{S}$ o c r a t e s : And now, if, Meno, the drama would not be left at being performed once, but if it would be performed over and over again - would it not be possible for us to maintain that the part of life shown to us by the poet in his drama repeats itself over and over?

M e n o : Certainly, Socrates.

$\mathrm{S}$ o c r a t e s : Then, Meno, think about it being thus, that in Nature the same play is performed to us over and over again.

M e n o : Can you give me an example for that?

$\mathrm{S}$ o c r a $\mathrm{t}$ e $\mathrm{s}$ : Look into your garden. There you see a tiny songbird collecting stalks to build his nest. Without any reasoning he chooses the right one each time and adds it to the elaborate fabric of his nest, his children's future home. No one taught it how to build a nest. No one told it that it is going to have children.

M e n o : That is indeed astonishing! Could it be that the bird has foresight?

$\mathrm{S}$ o c r a t e s : Does it not seem to you to be more probable that it has some knowledge stemming from a former existence, like the actor has it who lived through his rehearsals?

M e n o: Yes, this seems to me to be the truth.

$\mathrm{S}$ o c r a t e s: Is it not this knowledge stemming from a former existence, which is called by the trivial name of 'instinct'?

M e n o: Yes, it is as you say, Socrates.

$\mathrm{S}$ o c r a t e s: Only as far as the bird has this knowledge it is able to foresee things. Xenocrates had a tamed owl to which he had entrusted two duck eggs for breeding. When the ducklings crept out of 
their eggs, mother owl tried to feed them with a dead sparrow which she had torn apart as food for her young.

$\mathrm{M}$ e $\mathrm{n}$ o : Indeed, this shows that the owl had no foresight, but some knowledge about something rehearsed earlier.

$\mathrm{S}$ o c r a t e s : But since it never had had offspring before, this knowledge must have stemmed from a former life.

$\mathrm{M}$ e $\mathrm{n}$ o : Even the nightingales in my garden, when they begin singing their beautiful songs, should they be applying their knowledge of a melody learned in a former life? Is this what you mean, Socrates?

$\mathrm{S}$ o c r a t e s : Certainly this is what I mean, and does it not appear to you as if the melody of a nightingale's song is a rule of tones, as the act of building a nest is a rule of movements?

M e no: This certainly is the matter.

$\mathrm{S}$ o c r a t e s : And is not the knowledge of these rules already sufficient to sing the song correctly and to build the nest correctly?

M e n o: It seems so.

$\mathrm{S}$ o c r a t e s: Thus it is the knowledge about these rules which the living things carry in their memories. Thus being, it also were the rules comprising geometry that I brought out of your slave's memory again through my questioning.

M e n o : Certainly he carries some knowledge hidden to himself.

$\mathrm{S}$ o c r a t e s : And this hidden knowledge is comprised by rules.

$\mathrm{M}$ e $\mathrm{n}$ o : Could it be that there are men who know about certain rules unknown to other men?

$\mathrm{S}$ o c r a t e s: This indeed seems to be the case. For there are people like Xenophon who are unable to sing the simplest song properly, because they do not know the rules of the tones - whereas others, like Alcibiades, are outstanding singers.

$\mathrm{M}$ e $\mathrm{n}$ o: Therefore we distinguish between those men who have a gift for music and those who lack musicality.

$\mathrm{S}$ o c r a t e s : And we rightly do so. For some master the rules of the tones from the time of their birth onward, whereas some do not.

$\mathrm{M}$ e $\mathrm{n}$ o : Thus you believe that some owe their knowledge to a previous existence, whereas some have not inherited this knowledge, although they no doubt know about the existence of those rules and occasionally search for them, too. Thus some croak like ravens and some sing like nightingales, just like these two species of birds have brought their knowledge about different melodies from their previous lives. But to me such an assumption appears to be unnecessary. 
S o c r a t e s: What do you mean by your words, Meno?

$\mathrm{M}$ e $\mathrm{n} \mathrm{o}$ : This is what I mean: Even within a drop of water the rule of turning into an ice crystal is invisibly present, coldness being the only condition for enforcing the rule of crystallization.

S o c r a te s: What more?

$\mathrm{M}$ e $\mathrm{n} \mathrm{o}$ : Well, the knowledge about this rule is certainly not present within the drop of water, but the water drop is simply playing his role, like an actor.

$\mathrm{S}$ o c r a t e s: And now you believe that the nightingale as much as the drop of water is governed by its role like by a rule, sometimes forcing it to sing, sometimes to build its nest?

$\mathrm{M}$ e $\mathrm{n}$ o : That is exactly what I mean, Socrates. And therefore your assumption of a hidden knowledge stemming from another life would be invalid.

$\mathrm{S}$ o c r a t e s : My dear Meno, certainly you would be right, if there were no difference between a drop of water and a nightingale, but both were inanimate. In order to be able to acquire knowledge one needs, before anything else, to have an organ not only possessing the ability of perceiving the events of the outside world, like the ears perceive sound and the eyes color, but also possessing the ability to transform perception into knowledge; that is to say, to recognize its meaning. And now observe the little bird, how it confidently picks only those stalks which are meaningful to its nest-building, but leaves other stalks unpicked. You do not discover any of these qualities in a drop of water. It no doubt loses its shape to reappear in new shape, as ice crystal. Yes, one could say the rain dies as water in winter to be resurrected as ice in the shape of a snow flake, but the water drop does not notice it. It blindly obeys the commandments of Zeus, who hides his countenance one time with rainfall, another time with hailstorm, again another time with snowfall.

M e n o: Thus you, Socrates, believe that Zeus has ordained two roles to the water drop, the one of liquid water and the one of solid ice, replacing each other according to the rhythm of heat and cold, one time turning water into ice, another time turning ice into water.

$\mathrm{S}$ o c r a t e s : Certainly this is what I have in mind. Water and ice follow, without any restrictions, the roles Zeus implanted them, but they do not know anything about each other and about the world outside of them, for they do not possess any organ for remembering things and therefore no knowledge. But in bearing the roles appointed 
to them by Zeus they still are immortal and manifest themselves as soon as they are given the opportunity to do so.

M e n o : And how about plants, Socrates?

$\mathrm{S}$ o c r a t e s : Demeter has bestowed on them, like on all other living things, the succession of generations. The children always succeed their parents, becoming parents themselves. The same souls, having received their roles from Demeter, reappear again and again on life's stage, having to play the same roles over and over, but each time the Fates send them a different fate. At one time an acorn grows to become a great oak, at another time it dies in its youth.

$\mathrm{M}$ e $\mathrm{n}$ o : In the process, the appointed role and the bodily shape fitting this role are of the same kind.

$\mathrm{S}$ o c r a t e s : Do you not think, Meno, in this case one has to speak about immortality?

M e $\mathrm{n}$ o : I admit to that — but what distinguishes a plant from an ice crystal, except that the role of the plant includes more complex rules than the role of the crystal?

$\mathrm{S}$ o c r a t e s: First of all, the role of the crystal is carried through without being influenced by any outside events - except for the cold, whereas the roles of the plants are continuously influenced by their surroundings. All plants always grow upwards and their blooms turn towards the sun, while their leaves serve as gutters in order to supply their roots with water. Yes, after all, the role of the plants consists of adopting themselves to the outside world without having sensory organs, interacting with it in a way truly impossible for a drop of water.

M e n o : But you do not want to attribute knowledge to plants?

$\mathrm{S}$ o c r a t e s : No, as far as plants and small animals are concerned it is sufficient to assume that they merely repeat their roles, which Demeter once and for all assigned to her loved ones.

$\mathrm{M}$ e $\mathrm{n} \mathrm{o}$ : At all times defending the same role against the intervention of the Fates after all comprises the nature of the plants' soul.

S o c r a t e s: Your words exactly hit the point, Meno!

$\mathrm{M}$ e $\mathrm{n}$ o : Now we are getting to the large animals, which not only master their roles, but also know about their role and clearly see the meaning of their actions. Of course they need their memory of previously having performed the same role to assist them. If the bird would not possess a knowledge about nest-building from a previous 
life, it would be completely incapable of distinguishing the stalks meaningful to building his nest from those having no meaning to it as you have already explained, Socrates!

$\mathrm{S}$ o c r a t e s : I am glad that you now say the same things as I do.

$\mathrm{M}$ e $\mathrm{n}$ o : We admire those animals which are not only capable of performing simple tasks, but also are in the position of producing objects for which they lacked, as we thought until now, any model be it the bird's nest, be it the spider's web, be it the ball which the holy beetles of Egypt are capable of producing from dung. Now you have demonstrated that animals have to take their own actions from a previous existence as models, even if these actions appear to be completely inappropriate within their present lives, as was the case with the owl which tried to treat the ducklings as if they were young owls. That kind of actions is close to unknown within the lives of men. Men always observe the models of their present lives only. They do not possess an unforgotten knowledge stemming from a previous existence which could serve them as a rule for the actions of their present existence. Yes - it even was very difficult to prove that my slave possessed such a knowledge at all, forgotten and resting in him, only pulled back into light by your artful questioning.

$\mathrm{S}$ o c r a t e s: This certainly is remarkable.

$\mathrm{M}$ e $\mathrm{n}$ o : Can you tell for what reason the gods put us at such a disadvantage in comparison to the animals, for they have put man above animal in every other regard?

$\mathrm{S}$ o c r a t e s: You would find the disadvantage to be even greater if you made clear to yourself that man's imitations of the objects he has seen during his present life never are the equals of their originals - whereas the objects which animals are capable of producing by drawing from their inner knowledge always are the equals of their originals, sometimes even surpassing them.

M e $\mathrm{n}$ o : In this you are right, Socrates. The more justified is my question about the cause of this discrimination against man, for man indeed would never succeed in imitating even the simple nest of a songbird.

S o c r a t e s : Just think about it now, what may be the cause of this apparent disadvantage. The bird building his nest, even in case he repeats his task the following year, always has one choice only, i.e. to build exactly the same nest without any variation, because it always has to be made only according to the one original existing in its memory. 
And now imagine yourself to be in the position of a human architect who has been commissioned to build a number of new houses, which are to meet the needs of various clients, the architect possessing only one model of a truly beautiful but all the same stereotypical house from a previous life. And go on to imagine our great Praxiteles had only a single model for every of his likenesses of the gods in his memory would he then still be in the position to delight our eyes and hearts by ever new, ever more marvelous likenesses?

$\mathrm{M}$ e $\mathrm{n}$ o : In this you are right. For the price of all our mediocre craftsmen and architects being able to produce many different copies of existing things, the memory of the divine originals received from Nature has been taken from everyone. Only the truly inspired, on whom Apollo himself bestows the knowledge of a new image, have the gift to create a true original.

$\mathrm{S}$ o c r a t e s: But the god who robbed from man the knowledge from his previous existence nevertheless treated him hard, for he robbed from him the confidence pertaining to all actions of the other living beings. Yes, the god took from him the knowledge governing all the rest of the world.

$\mathrm{M}$ e $\mathrm{n}$ o: You do believe that confidence within Nature is based on an all-governing knowledge?

S o c r a t e s: I certainly believe so.

$\mathrm{M}$ e $\mathrm{n}$ o: Explain it to me by giving an example.

$\mathrm{S}$ o c r a $\mathrm{t}$ e $\mathrm{s}$ : You know the market in Piraeus, where the fishermen put their goods on offer?

M e n o : I certainly do.

$\mathrm{S}$ o c r a t e s : Do you remember those strange crabs living in a snail-shell, the back part of which is regarded as a delicacy by the common people?

$\mathrm{M}$ e $\mathrm{n} \mathrm{o}$ : Certainly, these crabs are called hermits, because everyone of them lives in his own house.

S o c r a t e s: Now, if we put the origin of the hermit crab's home under scrutiny, we see that it was with great certainty built by a snail to serve for its protection and as a dwelling as long as it lives. After the snail's death, the shell would uselessly lie on the bottom of the sea, unless a crab would have come to know about it through the knowledge common to Nature, and then confidently directed its own body's growth according to the design of the snail's shell. But this would not be sufficient. The crab itself must have been given its own 
knowledge of the snail's shell to accompany it on its life's journey, for as soon as its house becomes too small for it, it starts searching a new, larger one. If the crab finds a snail shell, many hundreds of which are on offer on the sea bottom to choose from, it examines the shell's size and durability. Then the crab quickly exchanges the shell for its old house by carefully hiding its soft rear part in the protective cover. This clearly demonstrates that the confidence of the body's design and the knowledge about someone else's house stem from the same root, which cannot be anything else than a divine natural knowledge revealing itself on one occasion in the structure of tissue, on another occasion in the actions of animals.

M e n o : Your explanations are quite convincing, Socrates. Thus plants as well as animals and men take part in divine Nature's knowledge through the structure of their tissue - but only animals in their actions draw their personal knowledge from this same source, whereas man in his actions has to rely on his own experience and therefore lacks confidence.

$\mathrm{S}$ o $\mathrm{c} \mathrm{r}$ a $\mathrm{t}$ es : It seems to me that the difference between human knowledge and Nature's knowledge is to be found in that respect, namely that man has to rely on his deceitful experience, whereas Nature's knowledge constitutes the structure of Nature herself and precedes all experience. That gives animals in their actions an advantage over our actions.

M e n o: What shall we do to compensate for this disadvantage?

$\mathrm{S}$ o c r a t e s : Does it not seem to you that Nature, who uses her knowledge to design the animals' bodies, has also applied it to bestow on them their role in life?

M e n o : Certainly.

$\mathrm{S}$ o c r a t e s : Now, animals know their role directly, but man does not and from this results his lack of confidence. Should it therefore not be our most important task to track down this knowledge about our own role?

M e n o : It indeed seems to be so.

$\mathrm{S}$ o c r a t e s : Only if man realizes the divine knowledge that constructed his body and bestowed his role on him, and if he keeps the purity of his soul, he will at the end of his days, when he gives up his body and with it his role, confidently return home into Nature's divine knowledge.

M e n o : I will never forget these words, Socrates! 


\section{Second Part}

S o c r a t e s: Thus a spirit reveals itself through all the creatures of Nature and their actions, an immortal spirit which is heard through all ages in the same manifold voice, a motherly basis underlying all created things. All living things realize this spirit through their growth as much as through their actions. Obeying an unconscious urge the shapes of the living things rise out of the spirit without becoming conscious of what they are realizing and what is driving them. And the things that were created by the spirit are absorbed back into it without having gained any consciousness of the process other than the unconscious natural knowledge which they take part in. They were never completely separated from the spirit, but they only agitated its surface, like waves agitating an ocean moving by its own harmonies. But human consciousness is knowledge of a different nature, it is so much different from that unconscious participation in the knowledge of the motherly basis that it within the sphere of man's consciousness eternally separates him from the confidence given by unconscious knowledge.

$\mathrm{M}$ e $\mathrm{n}$ o : That all the living things in their becoming and their actions, 'instinct', as we call it trivially, take part in a knowledge impossibly being acquired by them in their present lives, this idea, Socrates, appears to me to be beautiful and true. But I have to contradict you when you say they acquired it in a previous life which they spent on Earth in a similar shape.

$\mathrm{S}$ o $\mathrm{c} \mathrm{r}$ a t e s : What kind of argument are you bringing up again now, Meno? You claim they have acquired it neither in a previous nor in their present life?

$\mathrm{M}$ e $\mathrm{n} \mathrm{o}$ : That is just what I claim, namely that a memory of previous experience does not explain the knowledge about the laws of Nature.

$\mathrm{S}$ o c r a t e s: There you put yourself in a difficult position if you maintain that the living things do have knowledge but did not acquire it, neither now nor previously.

M e n o : You are right, Socrates, I feel like the stingray hit me again; that is why I again make the request to you to assist me.

$\mathrm{S}$ o c r a t e s: I will try, but first tell me exactly what you mean.

M e n o : I imagine the bird, which we saw building its nest in my garden, were the first of his species, just having risen to the light from 
the creating elemental forces of the cosmos; whereupon I begin to feel pity for the unfortunate creature, which lacks the possibility of calling on the experience of previous lives. Not only it will not be able to build its nest, it probably will hardly survive for more than a few days, not even knowing where and how to find its food. And I imagine all living things to be in the same pitiful position, even my slave and myself, even including you, Socrates. Before having been able to make the slightest experience on geometry, we will starve to death, or drown, or fall down a slope. And even if a merciful god would save us from this fate, giving us food and drink, we would be unable to cope with our wildly confused sensory impressions in such a manner as to make the simplest experience.

$\mathrm{S}$ o c r a t e s : Thus you are saying that every living thing's existence, be it the simplest or the most complex one, already requires knowledge, thus one cannot imagine it is acquired through experience.

$\mathrm{M}$ e $\mathrm{n} \mathrm{o}$ : Just as it is unimaginable that a man without possessing a non-acquired knowledge of the basic laws of space will make the slightest geometric experience; as it is unimaginable that a fish, thrown upon land by a storm, will then learn to find its way on dry land, for which he lacks every precondition.

$\mathrm{S}$ o c r a t e s : Therefore you think scientists should try to understand how hereditary qualities are acquired before studying how acquired qualities are inherited?

M e n o : That is just what I mean, Socrates.

$\mathrm{S}$ o c r a t e s: And what do you believe we have to imagine the acquisition of qualities to be like?

$\mathrm{M}$ e $\mathrm{n}$ o : You said earlier that one has to distinguish between man's conscious knowledge and the unconscious participation in common natural knowledge. And therefore I believe that one cannot imagine the acquisition of this knowledge to be of the same kind as the acquisition of human knowledge, but that it is an original knowledge without beginning, possessed by the first of all living things as much as by the last of them.

$\mathrm{S}$ o c r a t e s: By that you claim there can be no progress and no evolution of life, neither of the same living thing in different lives nor of successive generations.

M e n o : I think this idea improperly transfers human concepts onto natural processes, for such progress and evolution can be found only within man's conscious knowledge and its tradition; but 
transferred onto Nature this idea reduces itself to absurdity. For the whole problem of human experience and its tradition has absolutely nothing to do with our question, which deals with that kind of knowledge which must precede all experience. But a man who would grow up without gaining any knowledge about his ancestor's experience, would not be more wise but more stupid than a wild animal.

$\mathrm{S}$ o c r a t e s: And in spite of this you believe that one can extract from him by appropriate questioning the hidden knowledge which, so to speak, constitutes the semen of or precondition for all human development.

M e n o : You proved this to me earlier on my slave, Socrates. But I still want to believe that there is a difference between my slave's hidden knowledge and that knowledge revealing itself through the actions of animals.

S o c r a t e s: What do you mean by that, Meno?

M e n o : By this I want to say that both types of knowledge in fact must be without beginning and original in the same way, for they cannot result from experience, but that they differ in the way they reveal themselves.

$\mathrm{S}$ o $\mathrm{c} \mathrm{r}$ a t e s : If I understand you the right way, Meno, then you believe in the existence of an original knowledge revealing itself as nightingale knowledge in nightingales, as owl knowledge in owls and also as a knowledge of man as a living being in man, insofar as it concerns that part of his actions and fate that he shares with animals. This knowledge reveals itself directly through the actions of living things, without them becoming conscious of it. But the knowledge that we discovered in your slave also must be an original knowledge, the experience of space being unimaginable without it, but revealing itself only if being raised up into man's consciousness.

$\mathrm{M}$ e n o : You expressed very well what $\mathrm{I}$ have in mind. For we agreed for good reasons to describe as a common natural knowledge the unconscious knowledge of the various animal species as well as of man, insofar as he as a living thing belongs to Nature, because the various species reveal a knowledge about the physical structure and habits of other species, like the spider in building its web reveals a knowledge about the physical structure and habits of flies; therefore we have to describe the other kind of original knowledge as the common original knowledge of man, because we find it only in him, but there in every individual. But experience can be made in both 
spheres of knowledge, though to a completely different degree in the human sphere. But experience dies with the individual which made it. And the experience of an individual man's life also perishes with him and has to be taught anew to each child through tradition, in speech and writing. Human experience lives only by tradition and therefore language and writing are to be regarded as truly divine gifts, only they make it possible for man to be himself.

$\mathrm{S}$ o c r a t e s: But the original knowledge about measure, number and spatial relations is reborn with every man, whereas the world built by man through the course of thousands of years, applying his experience based on this knowledge, lives and dies together with tradition. But as far as animals are concerned, their individual experience always dies with the individual, for they have no tradition in the human sense.

M e n o : And, as you, Socrates, have shown earlier, the animals of our world do not need something like human tradition at all, for Nature shows herself in all their actions in her original way, and they carry out Nature's knowledge without having to give account for it to themselves.

$\mathrm{S}$ o c r a t e s : Indeed, Meno, I admit to having found in you an apt student of midwifery, with whom it is worthwhile to examine the hidden interrelations of life. Therefore you believe the world of human experience to be a world of giving self-account, not found anywhere with animals and belonging of living things to man alone. Now let us examine why man attained this special position and what we can conclude from it.

M e n o : Yes, Socrates, this seems to me to be one of the great questions, but I admit I cannot see any way of getting us closer to an answer.

$\mathrm{S}$ o c r a $\mathrm{t}$ e $\mathrm{s}$ : Did you ever hear the story being told of Prometheus, who, at mankind's dawn, robbed fire from the gods and brought its bright flame to man?

M e n o : Surely I heard the myth being told, and also how the gods, angered by the crime, seized Prometheus and forged him onto a rock for eternal torture.

$\mathrm{S}$ o c r a t e s: Thus hear now what I heard being told by priests and wise men: After Prometheus had brought the light of the eternal flame to man, the gods punished not only Prometheus, but they also turned man's eyes around so that he cannot see fire itself, but only its 
twitching reflections and the shadows cast by illuminated objects. But since that day man is unable to see the things themselves just as he cannot see fire itself, for his eyes have been turned around. Thus since that day man does not anymore live in the realm of his motherly world, i.e. knowledge unconsciously realizing itself, but also not in the realm of light, but in an intermediate realm of twilight; for man also is only capable of observing of the things and living beings in front of his eyes the flitting shadows emitting from them. But the things and living beings, the shadows of which he perceives, are like man himself expressions of the original motherly natural knowledge, from which stems all that has come to be. But the shadows cast by them are reflections of the divine fire lit by Prometheus behind the things, the blurred shapes of which inhabit man's world since that day. And of themselves, men also realize only the shadowy shapes. The realm of original motherly natural knowledge, giving birth to all living things, men, animals and plants, unconsciously realizes itself and lacks consciousness, in which solely exist shape, form and law. Thus it is the ideas of man, as rays of the divine light, which bestow contours and shape on the motherly natural knowledge. But man, hit by the rays of the divine fire, is excluded from the original confidence bestowed by the motherly knowledge on its creatures. He is forced to construct his own human world, in which both embrace and merge with each other. Thus therefore seems to me to be the position and the purpose of man, as determined by Prometheus' deed: He must spend his life as the being of an intermediate realm between the shadowy forces of eternal Nature and the realm of immortal divine light, belonging to both spheres, but not at home in any of them. But it is this transitory human world where the divine and the demonic spheres meet and merge.

$\mathrm{M}$ e $\mathrm{n} \mathrm{o}$ : And just as it is not given to us to see our own eyes, except by looking in a mirror, you believe it is not given to us to see the light of the spirit and its ideas, except in the mirror of the world where the ideas, reflections of the divine flame in which they have their origin, realize themselves. When I understand you correctly, Socrates, this is what you want to say by your parable about the gods turning around our eyes, so that we may not see fire itself, only its reflections and its silhouette.

S o c r a t e s : I interpret the legend, which I heard being told by priests and wise men, just as you do, Meno. They can speak on the 
origin and development of human existence, but only by metaphors and parables; for it does not become mortals to inquire into this matter. Although it definitely seems to me to be our duty to inquire and understand if their parables correctly describe the state of our world; for we can in this matter call on our experience, both on the experience which we gain through our own consciousness and our resulting actions and on the experience of other living things and the their actions resulting from it, because we participate in their experience inasmuch as we are living things.

$\mathrm{M}$ e $\mathrm{n}$ o : In that I agree with you, Socrates. And certainly also in allowing us to trust the priests' stories about a question as far-reaching as man's personal immortality only insofar as they give a true impression of our existence. But we have to remain suspicious in every other respect, for we do not know if they tell the truth or just maintain something in order to please themselves and us. Therefore I now venture to return again to the original question, about which I am so concerned that earlier I already could not be satisfied by your explanations, but had to press you to continue on the path together with me.

$\mathrm{S}$ o c r a t e s: Then tell me, what insights on this question can, in your opinion, be gained from our inquiries?

M e n o : I actually had ambiguous feelings earlier, when you, Socrates, said that a man, having found the common natural knowledge which brought forth his body and assigned his role to him, could at the end of his days, after discarding his role together with his body, confidently return into the divine knowledge of Nature. At first, it seemed to me that realizing a common natural knowledge, to which we owe our roles as living things and our bodies, does in no way indicate a previous existence as living beings, for we could never have acquired our part of this knowledge, but carry it with us as knowledge without origin. It rather seemed to me that Nature speaks to us at all times through our bodies' growth and through the roles she makes us play; of course she does not use any of the human languages.

$\mathrm{S}$ o c r a t e s : Yes, Meno, as it seems to me, you provided convincing evidence for what you claim.

$\mathrm{M}$ e $\mathrm{n}$ o : Thus everything seems to point in that direction that we, at the end of our days, do not only discard our bodies and our roles, but also our individual existence which is but the primary condition for what we call personality; for a previous existence cannot be proven 
and for our memory of hidden knowledge obviously being nothing else than the realization of the words Nature speaks to us at all times. The words from which our bodies and our roles as living beings arose, Nature takes back into herself, while we dissolve into the motherly source which brought us forth, like a drop of water falling into the ocean.

$\mathrm{S}$ o $\mathrm{c} \mathrm{r}$ a t e s : Looking on things from this angle, your conclusion seems to be unavoidable.

M e n o : Well, this kind of immortality or, as it should rather be called, dissolution seems to be no better than the so called immortality which the materialists comfort themselves with by saying: Not a single atom of all the parts of our body perishes, but is simply returned to the universal cycle of matter. And they comfort themselves with the idea of their body parts continuing to exist in future as dust, rain or whatever else.

$\mathrm{S}$ o c r a t e s: You make me laugh, Meno, when I see the heavy weaponry you put up against me. But there just seems to me to be a certain difference between the idea of continuing one's existence as dust, ashes or rain and the idea promising one's unification with the omniscient spirit of Nature.

M e n o : I would be the last one to deny that, but no one of the two promises personal immortality. And inasmuch as, according to the materialist faith, the wicked man is with his death released of both his body and the wickedness of his soul, the aspirations of the good man and the crime of the wicked man have also been in vain to the same degree; for man's relation towards Nature as a living thing is all that remains, but this relation is absolutely the same for both of them.

$\mathrm{S}$ o c r a t e s : Meno, because you are pressing me so hard I must admit that realizing one's participation in the common natural knowledge is not sufficient for understanding man's special position and his striving for truth and rightousness. If there were nothing except for this knowledge, man's striving would indeed be in vain, nothing else than deceiving himself.

$\mathrm{M}$ e $\mathrm{n} \mathrm{o}$ : But you do not want to maintain that view, do you, Socrates?

$\mathrm{S}$ o c r a t e s : You are like one of those ferocious hunting dogs not letting go of their game even when their already made the kill. In this dispute, I surrender to you and beg you to show mercy on me. 
Please show me how I erred. You are not going to deny that we conducted a zealous and honest inquiry?

M e n o : I do not deny it in any way, Socrates. Just like you, I am convinced that the results of our inquiry are correct.

$\mathrm{S}$ o c r a t e s : Therefore personal immortality does not exist and virtue, our initial subject, is a meaningless illusion entertained by man?

M e n o : It would appear to be like that if we forgot that the human world is not limited to realizing the original natural impulse, but a world of giving self-account in every regard. We saw earlier that man only to some degree originates from the unconsciously creating sphere of Nature, and that in his spirit lives a reflection of the divine flame, of which it is said it originated in Prometheus' crime. This ambiguous nature of human knowledge also seems to be of great importance to our question. For we saw everywhere how man impresses the flame of his consciousness on his world, even when he as a little child starts finding his position in the world, man's consciousness definitely being different from Nature's unconscious creating knowledge. And your parable appears to me to be beautiful and convincing: That we live in a world of twilight, observing of the divine light only what is reflected by Nature's creatures, like illusions of a dream, but being denied by the gods to see the flame itself, since they have turned our eye's around

$\mathrm{S}$ o c r a t e s: And what effect, in your opinion, has man's double nature on answering our question?

$\mathrm{M}$ e n o : For man stems from two different spheres, it seems to me, my dear Socrates, that it will turn out at the end of his days, if he will, following the general gravitation of his physical nature, dissolve into the shadowy source of all natural existence; or if he will, being forged well enough by the divine flame, become light and pure enough to attain a higher spiritual existence.

$\mathrm{S}$ o c r a t e s: But how do you imagine this higher existence to be like, Meno? Do you believe man's soul to be torn apart into two pieces, an earthly and a spiritual one, which afterwards part from each other, returning to their respective spheres?

M e n o : No, I do not believe it to be like that. It rather seems to me that Nature herself, insofar as she has been under the spell of the spirit's light, enters a higher existence. I am drawn to the conclusion that man is given one goal in everything he does: To raise Nature up 
into spiritual consciousness. And I believe that we clearly are 'human' in the true sense of the word only insofar as Nature attains spirit through us; for we may see the light of the divine flame only in the world's mirror, on which it is cast through us. But to a certain degree it seems to be put in our hands, Socrates, in which way the light shines onto the world, clear or blurred, pure or refracted and darkened by instinct. Thus every look a man takes into Nature bears witness on his quality as a human medium, depending on him, if he seeks truth, goodness and beauty or if he looks out for satisfying the desires of his instinct. Thus all our words, looks and actions influence how things around us evolve. The things around us reflect ourselves, they are a mirror which is either lit up by the divine flame or stays what it has always been, a part of Nature's original, shadowy existence. In the second case, man passes his life in vain and the world just remains what it has been without him. But in the first case, man will retain that kind of spiritual shape and personality that corresponds to spiritualized Nature. And thus it seems to me, Socrates: Whoever sees the workings of unconscious Nature in a spiritual light clear enough to make her shine and speak in a way man will understand, he will during his lifetime imprint the clarity of his personal existence on Nature, and he will never loose that clarity.

\section{Вечный вопрос: биологические вариации одного платоновского диалога}

Биологическая реинтерпретация природы, которая преобладает несмотря на все препятствия, приблизила наше мышление к античности и дает возможность оживить нашу разработанную терминологию с помощью рессурсов мысли величайших умов человечества. Очищая таким образом путь к Платону, я задумал искать просветления, задавая биологические вопросы этому мыслителю. В этих целях я продолжил диалоги Сократа, давая ему информацию о современных биологических проблемах. Так, принося нам ощутимую пользу, создан мост между нами и античной мыслю. Текст опирается на диалог Платона "Менон”. Первая часть написана Якобом фон Юкскюллом, вторая его сыном Туре фон Юкскюллом. Впервые он был опубликован в 1943 году и здесь мы имеем, видимо первый опубликованный перевод на английский язык. 


\section{Igavene küsimus: \\ Bioloogilised variatsioonid ühele Platoni dialoogile}

Looduse tõlgendamine bioloogia poolt, mis valitseb kõigile tõketele vaatamata, on toonud meie mõtlemise lähemale antiigile ja annab võimaluse ergastada meie läbitöötatud terminoloogiat inimkonna suurvaimude mõtteressursside kaasabil. Puhastades niiviisi teed Platoni juurde, tulin mõttele otsida valgustust bioloogiliste küsimuste küsimise kaudu mõttetargalt. Selleks panin Sokratese jätkama oma dialooge, andes talle teadmisi tänapäevastest bioloogilistest probleemidest. Nii on loodud teatav kokkupuude antiiksete mõtlejate ja meie vahel, meie märgatavaks kasuks. Tekst tugineb Platoni dialoogile Menon; esimese osa on kirjutanud Jakob von Uexküll, teise tema poeg Thure von Uexküll. Esmakordselt avaldati see 1943. aastal, käesolev on arvatavasti esimene avaldatav tõlge inglise keelde. 